\title{
UTILIZATION CHEMIGATION TO REDUCE PEAS CONTAMINATION WITH PESTICIDE IN NEW RECLAIMED LANDS
}

\author{
HUSSIEN. A.A. \\ - Agr.Eng.Inst.ARC, Dokki, Giza, Egypt. \\ (Manuscript received 13 December 2018)
}

\begin{abstract}
$\mathrm{T}$ he aim of this study is to reduce Peas contamination with herbicide by applying chemigation in new reclaimed lands through drip irrigation systems. The herbicide (butralin) was injected with recommended rate $(2.5 \mathrm{Kg} / \mathrm{Fed})$ through subsurface and surface drip irrigation systems with two flow rates of 8 and 12 $\mathrm{l} / \mathrm{h} / \mathrm{m}$ tube under sandy soil conditions in winter and summer seasons 2016. The results showed that the highest productivity of the peas was (5570 kg / Fed) with water use efficiency (WUE) of $(2.31 \mathrm{Kg} / \mathrm{m} 3)$ and more uniformity under the following conditions: the subsurface drip irrigation system at an flow rate of $8 \mathrm{I} / \mathrm{h} / \mathrm{m}-$ tube (dripper flow rate of $4 \mathrm{l} / \mathrm{h}$ ) and $50 \mathrm{~cm}$ emitters spacing, injection of the herbicide (butralin). It is wearthly to mention that no (butralin) residues were found in Pea yield produced under subsurface drip irrigation systems $(10 \mathrm{~cm}$ depth), $50 \mathrm{~cm}$ emitters spacing and $8 \mathrm{l} / \mathrm{h} / \mathrm{m}$ flow rate under the manured sandy soil.

Keywords: Drip irrigation, Herbicide (Butralin), Water use efficiency.
\end{abstract}

\section{INTRODUCTION}

The increasing of application both water and agro-chemicals is contributing in environmental problem and human health hazard. So, the cultivating in new reclaimed land with modern techniques such as micro irrigation (drip), fertilizer and protections should be eliminated these problems.

Egyptian government has targeted to increase Pea production in new lands cultivations. The cultivated area reached 19525 fed in 2013 up from 6796 fed in 1995. The increasing ratio was $65 \%$ (Agricultural Statistics, 2013). Application of pesticide through a drip irrigation system adds a new dimension to irrigation system and becomes a multifunction unit able to supply crops with necessary water and agrochemicals at the same time (El-Gindy \& El-Araby, 1996 and Locascio et al., 1997). The advantages of drip-injection of insecticides over ground application methods include a uniform distribution of insecticide throughout the plant; a reduction in pesticide application inputs, including manpower and vehicle or tractor fuel; and a reduction in soil compaction, plant disturbance, and applicator exposure to pesticides. Insecticides applied through a drip irrigation system can replace or reduce the number of foliar insecticide sprays, reducing the risks to nontarget species (Gerald et al. (2012). The emitters' line materials and other equipment must be resistant to 
chemicals that may be injected into irrigation system, such as fertilizers, bactericides, insecticides, herbicides and fungicides (Nakayama et al., 1979). Application of pesticide through an irrigation system from a drip source is not prone to aerial drift away from the treated area as in the case with sprinkler and sprayer application. Also, there is less potential for pesticide transport by runoff and erosion because there are no pesticide residues on the plant and soil surfaces to wash off (Threadgill, et al., 1990). Applications of butralin (3000 p.p.m.) increased shoot growth in the tree head and stem thickening (Quinlan and Pakenham,1984). The control of $C$. album and $S$. nigrum was achieved with butralin by $94 \%$ and increased yields by $17-29 \%$ in soybeans (Regnault, 1986). Low rates of butralin did not control the weed, but normal recommended doses resulted in $85 \%$ control. (Demirci and Nemli, 1996). Monitoring and settings of maximum residue levels for pesticide residues in food commodities is an effective control mechanism for safety of the consumers to combat health impacts of toxic chemicals. There is evidence to show that consumption of organic crops is healthier than non-organic. In most of the research findings higher pesticide residues are found in non-organic crops than organic ones, organic crops are also rich in antioxidants. Processing method like washing, immersing, peeling, husking, cooking, boiling and frying are reported to reduce the level of pesticide residue in plant foods (Kumera and Neela 2016). It suits a pest management program well because many of the new-chemistry insecticides labeled for drip/trickle irrigation system application are selective to specific insect pests and, because they are applied to the plant root zone, are generally less toxic to beneficial and non-target organisms (Gerald, 2012). A safe and effective chemigation with drip and overhead irrigation system must include the following components: a functional check valve, vacuum relief valve and low pressure drain on the irrigation pipeline to prevent water source contamination from backflow. The pesticide pipeline must contain a functional, automatic, quick-closing check valve to prevent the flow of fluid back to the injection pump.

1- The pesticide injection pipeline must also contain a functional, normally closed, solenoid-operated valve located on the intake side of the injection pump and connected to the system interlock to prevent fluid from being withdrawn from the supply tank when the system is either automatically or manually shut down.

2- Further, the system must contain a functional interlocking control to automatically shut off the pesticide injection pump when the water pump motor stop.

3- Finally, the water pump must include a functional pressure switch which will stop the water pump when the water pressure decreases to the point where pesticide distribution is adversely affected (Rutgers, 2018). There is an urgent need to educate farmers around Hyderabad megacity to practice organic farming to grow vegetables and other crops to minimize the use of chemical pesticides in order to avoid adverse effects of pesticide residues in urban water bodies and also in food chains. The 
organic farming practices when adopted have demonstrated its effectiveness in reducing the use of pesticides in farming which resulted in lower pesticide residues (Rajeshwari et al., 2011). The aim of this study is to reduce Peas contamination with herbicide by applying chemigation in new reclaimed lands through drip irrigation systems

\section{MATERIAL AND METHODES}

\section{Experimental layout:}

The experiments were carried out during 2016 in private farm (green revolution $\mathrm{Km} 31$ Egypt-Alexandria road after the intelligent village). The farm has the latitude of $30^{\circ} 04^{\prime} 37.0 \mathrm{~N}$ the longitude of $30^{\circ} 59^{\prime} 53.5 \mathrm{E}$. The experimental area of $400 \mathrm{~m}^{2}(20 \mathrm{~m} \mathrm{x}$ $20 \mathrm{~m}$ ) was divided into two plots $10 \times 20 \mathrm{~m}$ for surface and subsurface (10 cm depth) drip irrigation systems (Fig1). Every plot was divided into four subplots. The first four subplots assign to flow rate $8 \mathrm{l} / \mathrm{h} / \mathrm{m}$-tube with $50 \mathrm{~cm}$ emitters spacing under surface drip irrigation system. The 1 st and $2{ }^{\text {nd }}$ subplots of them carried out under sand soil and the $3^{\text {rd }}$ and $4^{\text {th }}$ subplots sand soil with manure under subsurface drip irrigation system (Farm manure was added to sandy soils with $20 \mathrm{~kg} / \mathrm{Fed}$ ). The second four subplots irrigated by flow rate $12 \mathrm{l} / \mathrm{h} / \mathrm{m}$-tube (33 $\mathrm{cm}$ between drippers) with sand soil and sand soil with manure (Farm manure was added to sandy soils with $20 \mathrm{~kg} / \mathrm{Fed}$ ) at the same procedures with the first four subplots. Every plot was treated by Butralin (Amex) and injected through the drip irrigation systems by using positive displacement magnetic pump after one month of planting as a protection treatments. Pea seeds were sowed on 1 October, 2016.

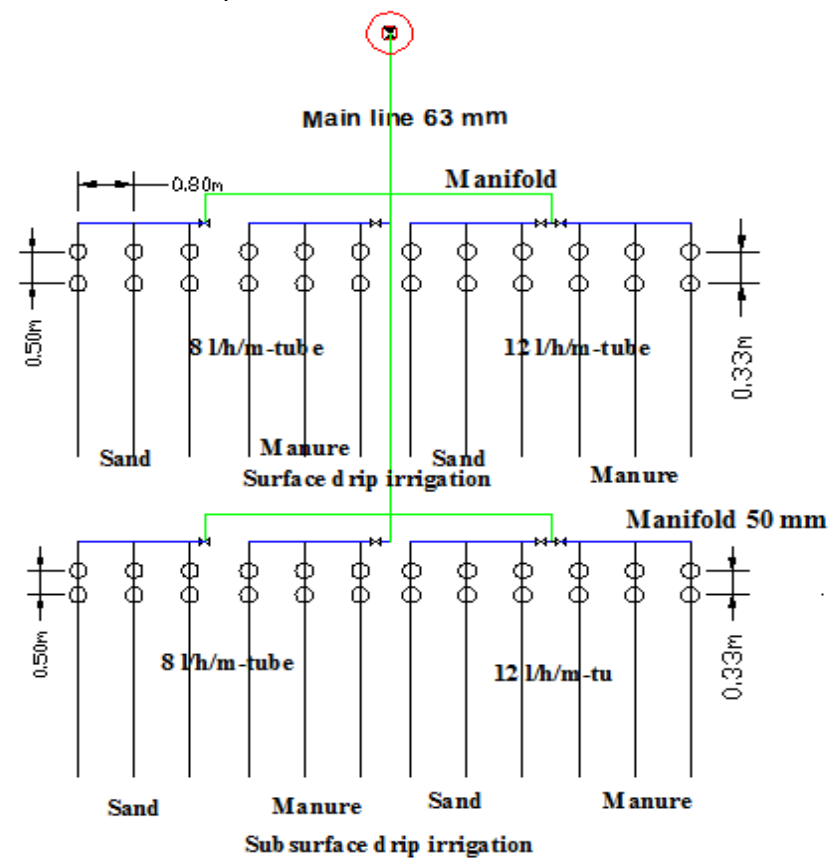

Fig 1: The experimental layout 


\section{Herbicide characteristics}

Herbigation studies were conducted for limiting herbicide contamination on Peas in new land via drip irrigation systems (surface and subsurface). According to Ministry of Agriculture Herbicide (Butralin) was applied with the recommended rate of $2.5 \mathrm{~kg} / \mathrm{fed}$. According to Hartley and Kidd (1985) Butralin having the following characteristics:

-Molecular formula: $\mathrm{C}_{12} \mathrm{H}_{21} \mathrm{~N}_{3} \mathrm{O}_{4}$

-Chemical name: 4-(1, 1-dimethylethyl)-N-(1-methylpropyl)-2, 6dinitrobenzenamine

- Solubility in water: $0.3 \mathrm{mg} / \mathrm{I}\left(25^{\circ} \mathrm{C}\right)$

-Toxicity classification (WHO) of formulation: Low III

-Environmental Fate in soil: 21 days.

-EPA classification: IV

-Toxicity: Male rat (Oral) LD 50 1170, female rats 1049 mg/Kg. Inhalation LC 50 for rats $>9.35 \mathrm{mg} / \mathrm{L}$ of air.

-Recommended tolerance: Code of federal register EPA revised July 1, $83: 0.1 \mathrm{p}$ p m.

\section{Determination of yield:}

Yield=Average weight fruit/ plant $\times$ Number of plant/fed

\section{Amount of irrigation water Applied:}

Table 1. Showing that :Growth period, References Evapotreanspiration (ETo),Crop Evapotreanspiration (ETC) and Crop Coefficient( $K_{C}$ ) according to( FAO 1998).

\begin{tabular}{|c|c|c|c|c|c|}
\hline & \multicolumn{4}{|c|}{ Growth period } & Total \\
\cline { 2 - 5 } & $\begin{array}{c}\text { Initial stage(25 } \\
\text { day) }\end{array}$ & $\begin{array}{c}\text { Development } \\
\text { stage(30 day) }\end{array}$ & Mid stage(35 day) & $\begin{array}{c}\text { Late stage(25 } \\
\text { day) }\end{array}$ & 1.05 \\
\hline $\mathrm{K}_{\mathrm{c}}$ & 0.45 & 0.8 & 1.15 & 4.8 \\
\hline $\mathrm{ET}_{\mathrm{o}}$ & 11.1 & 6.25 & 4.3 & 5.04 \\
\hline $\mathrm{ET}_{\mathrm{c}}$ & 4.99 & 5.00 & 4.95 & $25 \times 5.04=126$ & 574 \\
$\mathrm{~mm}$ & $\mathrm{~mm} /$ period & $\begin{array}{c}30 \times 5.00=150 \\
\mathrm{~mm} / \text { period }\end{array}$ & $\begin{array}{c}35 \times 4.95=173.25 \\
\mathrm{~mm} / \text { period }\end{array}$ & \begin{tabular}{c}
$\mathrm{mm} / \mathrm{season}$ \\
\hline Total
\end{tabular} & $\begin{array}{c}25 \times 4.99=124.75 \\
\mathrm{~mm}\end{array}$
\end{tabular}

As crop evapotranspiration ETc can be calculated as (Allen et al., 1998).

\section{$\mathrm{ETC}=\mathrm{ET} \mathbf{0} \times \mathrm{Kc}$}

$\mathrm{ETc}=$ Crop evapotreanspiration

$\mathrm{KC}=$ Crop coefficient

$\mathrm{ETo}=$ Reference crop evapotreanspiration

The amount of Crop water Requirements was ( $2411 \mathrm{~m}^{3} / \mathrm{Fed} / \mathrm{season}$ ) according to (Allen et al., 1998).

$$
\text { CWR }=E T C \times 4.2
$$

CWR $=574 \mathrm{~mm} /$ season/Fed $\times 4.2=2411 \mathrm{~m}^{3} /$ season/Fed

$\mathbf{C W R}=$ Crop water Requirements 


\section{Experimental Treatment:}

-Irrigation system: Surface and subsurface drip irrigation

-flow rate: 8 and $12 \mathrm{l} / \mathrm{p} / \mathrm{h} / \mathrm{m}$-tube flow rate

-Soil texture: Sand soil and sand soil with manure-

-Control treatment: Area $(10 \mathrm{~m} \times 10 \mathrm{~m})$. Soil: sand. Herbicide treatment: Non chemigation

Calculating water use efficiency (WUE): Water use efficiency WUE) was computed as following :( Howell et al., 1995).

W.U.E. $\left(\mathrm{kg} / \mathrm{m}^{3}\right)_{1}=$ Yield $(\mathrm{kg} /$ Fed $) /$ Water use $\left(\mathrm{m}^{3} /\right.$ Fed $) \times 100$

Determination of the relative productivity\% $=$ Treatment $/$ Control $\times 100$

Determination of pesticide residues in Pea fruits by Gc- chromatograms:

Determination of butralin residues in Pea fruits by Gc- chromatograms according to the Environmental Research Unit Toxicology, Faculty of Agriculture, Ain-Shams University.

\section{RESULTS AND DISCUSSION}

The effect of drip irrigation systems on Pea productivity can be presented in Table (2) that revealed the productivity of Pea ( $\mathrm{kg} / \mathrm{Fed}$ ) was affected by drip irrigation systems performances, distance between emitters, flow rates, and injected herbicide to the soil through irrigation. The highest yield value (5570 kg/Fed) was obtained by using the subsurface drip irrigation systems $(10 \mathrm{~cm}$ depth), $50 \mathrm{~cm}$ emitters spacing and sand soil mix with manure and of $8 \mathrm{l} / \mathrm{h} / \mathrm{m}$ flow rate chemigated by herbicide Butralin .The yield was increase by $26.6 \%$ as compared to no applied herbicide with subsurface drip irrigation systems. This may be due to the performance advantages of using the new of herbigation techniques. (Agarcio , 1985). On the other hand, the lowest yield (4075 Kg/Fed) was recorded by using herbicide with surface drip irrigation systems, emitters spacing $33 \mathrm{~cm}$, sand soil, and $12 \mathrm{l} / \mathrm{p} / \mathrm{h} / \mathrm{m}$ flow rate. The yield decreased by $7.4 \%$ as compared to no applied herbicide with surface drip irrigation systems. This may be due to the great interference between chemicals in the area of the root zone.

Data in the same table showed that the productivity with $12 \mathrm{l} / \mathrm{h} / \mathrm{m}$-tube was less than that of $8 \mathrm{l} / \mathrm{h} / \mathrm{m}$-tube. This may be attributed to the good performances of both tested drip irrigation systems and herbigation process in improving the water use efficiency and prevention weeds to share the nutriment with Pea plants. 
Table 2. Effect of butralin herbicide application through drip irrigation systems on Pea productivity.

\begin{tabular}{|c|c|c|c|c|c|c|}
\hline \multirow[b]{2}{*}{$\begin{array}{l}\text { Irrigation } \\
\text { system }\end{array}$} & \multirow[b]{2}{*}{$\begin{array}{c}\text { Soil } \\
\text { condition }\end{array}$} & \multirow[b]{2}{*}{$\begin{array}{l}\text { Applied flow } \\
\text { rate } 1 / \mathrm{h} / \mathrm{m} \text {-tube }\end{array}$} & \multicolumn{2}{|c|}{ Yield } & \multirow{2}{*}{$\begin{array}{l}\text { Yield of } \\
\text { control } \\
\text { treatment }\end{array}$} & \multirow{2}{*}{$\begin{array}{c}\text { The } \\
\text { amount } \\
\text { control of } \\
\text { water use }\end{array}$} \\
\hline & & & $\mathrm{kg} / \mathrm{Fed}$ & $\begin{array}{c}\text { Relative } \\
\text { productivity\% }\end{array}$ & & \\
\hline \multirow{4}{*}{$\begin{array}{l}\text { Surface drip } \\
\text { irrigation }\end{array}$} & \multirow{2}{*}{$\begin{array}{l}\text { Without } \\
\text { manure }\end{array}$} & 8 & 4949 & 112.5 & \multirow{8}{*}{$\begin{array}{c}4400 \\
\text { Kg/Fed } \\
\text { (Surface } \\
\text { (irrigation }\end{array}$} & \multirow{8}{*}{$\begin{array}{c}3520 \\
\mathrm{~m}^{3} / \text { season } \\
\text { (Surface } \\
\text { (irrigation }\end{array}$} \\
\hline & & 12 & 4075 & 92.6 & & \\
\hline & \multirow[t]{2}{*}{$\begin{array}{l}\text { With } \\
\text { manure }\end{array}$} & 8 & 5110 & 116.1 & & \\
\hline & & 12 & 4489 & 102.0 & & \\
\hline \multirow{4}{*}{$\begin{array}{l}\text { Subsurface } \\
\text { drip } \\
\text { irrigation }\end{array}$} & \multirow[b]{2}{*}{$\begin{array}{l}\text { Without } \\
\text { manure }\end{array}$} & 8 & 5041 & 114.5 & & \\
\hline & & 12 & 4436 & 100.8 & & \\
\hline & \multirow[b]{2}{*}{$\begin{array}{c}\text { With } \\
\text { manure }\end{array}$} & 8 & 5570 & 126.6 & & \\
\hline & & 12 & 4650 & 105.7 & & \\
\hline
\end{tabular}

Also, the results in Table (2): showed that the productivity of pea with12 $\mathrm{l} / \mathrm{h} / \mathrm{m}$ flow rate was less than that achieved with $8 \mathrm{l} / \mathrm{h} / \mathrm{m}$-tube flow rate by using both of subsurface and surface drip irrigation systems. This may be attributed to the good characteristics of both drip irrigation systems, herbigation approach, improve the water use efficiency and prevention weeds to share the nutrient of pea. Because of the close relation between the rate of soil intake and the actual flow rate for the irrigation systems, so the application of $8 \mathrm{l} / \mathrm{h} / \mathrm{m}$ flow rate may improve the sandy soil intake losses. This approach will reach to the highest graduate for water management under arid conditions.

As conclusion, the obtained results showed that, the use of subsurface drip irrigation systems buried at $10 \mathrm{~cm}$ depth, with $8 \mathrm{l} / \mathrm{h} / \mathrm{m}$-tube flow rate and $50 \mathrm{~cm}$ emitters spacing under mix soil proved more suitable to cultivate Pea, in comparison with other irrigation systems. These results are in agreement with Sultan, 2002 who found that irrigation systems with $8 \mathrm{l} / \mathrm{h} / \mathrm{m}$-tube flow rate, $50 \mathrm{~cm}$ distance between emitters, and $10 \mathrm{~cm}$ (subsurface) depth were more efficient to use in the new land for vegetable production.

In this concern, weed control by proper herbicide with subsurface drip irrigation systems, $8 \mathrm{l} / \mathrm{h} / \mathrm{m}$-tube flow rate, $50 \mathrm{~cm}$ emitters spacing , under sandy soil mix with manure proved necessary for achieving good production of pea (5570 $\mathrm{kg} / \mathrm{fed}$ ) with more uniformity in case of the suitable $8 \mathrm{l} / \mathrm{h} / \mathrm{m}$-tube flow rate .

Data presented in Table (3) show that water use efficiency (WUE) of pea was markedly affected by the drip irrigation systems characteristics and butralin 
application. The herbicide butralin showed the highest values of WUE 2.31 and 2.12 $\mathrm{kg} / \mathrm{m}^{3}$ with $8 \mathrm{l} / \mathrm{h} / \mathrm{m}$-tube flow rate were obtained when Pea was irrigated by subsurface buried at $10 \mathrm{~cm}$ depth and surface drip irrigation systems, respectively. The WUE was increased by $54 \%$ as compared to no chemigation treatment. Whereas the systems with $12 \mathrm{l} / \mathrm{h} / \mathrm{m}$ flow rate, $33 \mathrm{~cm}$ emitters spacing for surface and subsurface drip irrigation systems with sand soil showed the lowest WUE (1.69-1.83 $\mathrm{kg} / \mathrm{m}^{3}$ ). The other treatments gave an intermediate WUE values $\left(1.90\right.$ to $\left.1.86 \mathrm{~kg} / \mathrm{m}^{3}\right)$.

Table 3. Effect of butralin herbicide application through drip irrigation systems on Pea Water use efficiency WUE $\left(\mathrm{Kg} / \mathrm{m}^{3}\right)$.

\begin{tabular}{|c|c|c|c|c|}
\hline Irrigation system & Soil condition & $\begin{array}{c}\text { Flow rate } \mathrm{l} / \mathrm{h} / \mathrm{m} \text { - } \\
\text { tube }\end{array}$ & $\begin{array}{c}\text { WUE } \\
\left(\mathrm{Kg} / \mathrm{m}^{3}\right)\end{array}$ & $\begin{array}{c}\text { Yield } \\
\text { ( kg/Fed) }\end{array}$ \\
\hline \multirow{4}{*}{ Surface drip } & \multirow[t]{2}{*}{ Without manure } & 8 & 2.05 & 4949 \\
\hline & & 12 & 1.69 & 4075 \\
\hline & \multirow[b]{2}{*}{ with manure } & 8 & 2.12 & 5110 \\
\hline & & 12 & 1.86 & 4489 \\
\hline \multirow{4}{*}{ Subsurface drip } & \multirow[b]{2}{*}{ Without manure } & 8 & 2.09 & 5041 \\
\hline & & 12 & 1.83 & 4436 \\
\hline & \multirow[b]{2}{*}{ with manure } & 8 & 2.31 & 5570 \\
\hline & & 12 & 1.90 & 4650 \\
\hline
\end{tabular}

WUE Control $1.25 \mathrm{Kg} / \mathrm{m}^{3}$ (No chemigation)

Data concerning the residues of the herbicide butralin (Amex) in pea produced under drip irrigation system (surface and subsurface) and chemigation through growing stage of pea plants with irrigation water at 8 and $12 \mathrm{l} / \mathrm{h} / \mathrm{m}$ flow rates are tabulated in Table (4). Examination of the obtained result indicated the absence of pesticide residues in pea harvest. This finding was pronounced with the herbicide treatment with the two discharge rates of water 8 and $12 \mathrm{l} / \mathrm{h} / \mathrm{m}$ flow rate under subsurface and surface drip irrigation systems.

The disappearance of herbicide residues in pea grown under drip irrigation system (subsurface and surface) and chemigation treatments at two rates 8 and $12 \mathrm{l} / \mathrm{h} / \mathrm{m}$ flow rate in manured and sandy soils may be explained because the rapid degradation and hydrolysis of the tested herbicide in water and soil.

Also, microbial degradation may be played important role besides the adsorption of these compounds in soil. Our findings are in agreement with that obtained by Capri, et al., 1998 who reported that despite the large number of applications done during the cultivation of the crop no residue was found in the plant or the fruit (quantification limit $<0.01 \mathrm{mg} / \mathrm{kg}$ ). Under these conditions butralin showed a low environmental impact and was of low persistence and mobility in the soil profile. 
Table 4. Residues of tested herbicide (Butralin) in Pea under drip irrigation systems and herbicide use.

\begin{tabular}{|c|c|c|c|c|c|c|c|c|}
\hline \multirow[b]{4}{*}{$\begin{array}{c}\text { Pesticides } \\
\text { used }\end{array}$} & \multicolumn{8}{|c|}{ Residues in pea harvest (PPM) } \\
\hline & \multicolumn{4}{|c|}{$81 / p / h / m$} & \multicolumn{4}{|c|}{$12 \mathrm{l} / \mathrm{p} / \mathrm{h} / \mathrm{m}$} \\
\hline & \multicolumn{2}{|c|}{ Subsurface } & \multicolumn{2}{|c|}{ Surface } & \multicolumn{2}{|c|}{ Subsurface } & \multicolumn{2}{|c|}{ Surface } \\
\hline & $\begin{array}{l}\text { Manure } \\
+ \\
\text { Sand } \\
\text { soil } \\
\end{array}$ & $\begin{array}{l}\text { Sand } \\
\text { soil }\end{array}$ & $\begin{array}{l}\text { Manure } \\
+ \\
\text { Sand } \\
\text { soil } \\
\end{array}$ & $\begin{array}{l}\text { Sand } \\
\text { soil }\end{array}$ & $\begin{array}{l}\text { Manure+ } \\
\text { Sand soil }\end{array}$ & $\begin{array}{l}\text { Sand } \\
\text { soil }\end{array}$ & $\begin{array}{l}\text { Manure+ } \\
\text { Sand soil }\end{array}$ & $\begin{array}{l}\text { Sand } \\
\text { soil }\end{array}$ \\
\hline $\begin{array}{l}\text { Butralin } \\
\text { ( Amex) }\end{array}$ & N.D & N.D & N.D & N.D & N.D & N.D & N.D & N.D \\
\hline
\end{tabular}

N.D = Not-detected (Less than the limit of detection (LOD) of $1 \mathrm{ppb}$.)

According to the laboratory of Environmental Research Unit of Toxicology, Faculty of Agriculture, Ain-Shams University.

\section{CONCLUSION}

Reviewing the obtained results, it could be concluded that the application of butralin herbicide with subsurface drip irrigation systems, $50 \mathrm{~cm}$ emitters spacing and $8 \mathrm{l} / \mathrm{h} / \mathrm{m}$-tube flow rate and amended soil by added manure at $20 \mathrm{~kg} /$ Fed was more efficient in pea WUE and yield and resulted in the absence of herbicide residue in Pea yield. Drip irrigation systems with $8 \mathrm{l} / \mathrm{h} / \mathrm{m}$-tube flow rate proved more efficient to increase pea WUE than $12 \mathrm{l} / \mathrm{ph} / \mathrm{m}$ flow rate. Weed control by proper herbicide is necessary for achieving good WUE (2.31- $\left.2.12 \mathrm{~kg} / \mathrm{m}^{3}\right)$.

\section{REFERENCES}

1- Allen,R.G.,L.S.Pereira;D.Raes; and and M.Smith, 1998. Crop evapotrancpiration. Guidelines for computing crop water requirement.FAO Irrigation and Drainage. Paper No.56, FAO.Rome,Italy.

2- Agarcio, BC, Jr. 1985. Effect of phosphorus and nitrogen fertilization and weed control method on weed incidence and mungbean production.Dep. Agron. and Soil Sci., Visayas State Coll. of Agric., Baybay, Leyte, Philippines. Annals-ofTropical-Research. 7: 1-11.

3- Agricultural Statistics, Ministry of Agriculture. 2013. Summer and Nile crop, Volum 2 June 2012, pp (191-193).

4- Capri, E.; F Sicbaldi,.; N Vagnotti,. and M. Trevisan,. 1998. Ethoprophos residues in soil and in tomato after repeated applications by drip irrigation. Istituto di Chimica Agraria ed Ambientale, Universita Cattolica del Sacro Cuor, via Emilia Parmense 84 - 29100 Piacenza, Italy. Fresenius-Environmental-Bulletin. 1998, 7: 11-12, 734-737; 6 ref.

5- Demirci,M. and Y Nemli,. 1996. Pre emergence dinitroanilines for control of bristly foxtail (Setaria verticillata (L.) P.B.) in cotton production areas. dr. Ege 
Universitesi Ziraat Fakultesi Bitki Koruma Bolumu, 35100 Bornova, Izmir, Turkey. Ege-Universitesi-Ziraat-Fakultesi-Dergisi. 33: 2-3 and 129-134.

6- Douglas Hartley. 1985. The Agrochemical Hand Book. Royal Society of Chemistry; Revised edition (October 1, 1991).

7- EL-Gindy, A. M. and A.M EL-Araby,. 1996). Vegetable Crops Response to Surface and Subsurface. International Conference on Evapotranspiration and Irrigation Scheduling, San Antonio, Texas, November 3-6, 1996.

8- FAO. 1998. Crop evapotranspiration- Guidelines for computing crop water requirements-FAO Irrigation and drainage paper (56) P 105.

9- Gerald M. G., 2012. Insectigation in Vegetable Crops: The Application of Insecticides Through a Drip, or Trickle Irrigation System Integrated Pest Management and Pest Control - Current and Future Tactics, Dr. Sonia Soloneski (Ed.), ISBN: 978-953-51-0050-8.

10- Gerald, G. , K .Thomas, P John and S. David. 2012. Drip Chemigation of Insecticides as a Best Management Tool in Vegetable Production.

J. Integ. Pest Mngmt. 3(3): 2012.

11- Hartley, D., Kidd, H., Editors. 1985. The AgrochemicalsHand book. $2^{\text {nd }}$ dition, TheRoyal Society of chemistry,Nottingham,England.

12- Howell,T.A. A.Yazar,., A.D Schneider., D.A Dusek, and K.S Copeland. 1995. Yield and water use efficiency of corn in response to lepa irrigation.Trans of the ASAE 38 (6):1737-1747.

13- Jeff Howard, B.S. 1994. Method of The Determination of Butralin-CFPI. Agrochemical Division 28 Bd. Camelinat 92233 Gennevilliers, FRANVE. PTRL Project No: 774.PTRL REPORT No: 1605. Volume 1 of 1 of Study.

14- Kerry, A. H. and R. E. Skinner. 1981. why use chemigation, National symposium on chemigation Aug. 20-21 (1981), Rural development center Tifton, Georgia: 109. -112 .

15- Kumera, N. and S. Neela. 2016. Review on Pesticide Residue in Plant Food Products: Health Impacts and Mechanisms to Reduce the Residue Levels in Food.Scholars Research Library. Archives of Applied Science Research, 2016, 8 (3):55-60.

16- Locascio, S.J.; J.P. Gilreath; D.W. Dickson; T. A. Kucharek; J. P. Jones and J. W. Noling. 1997. Fumigant alternatives to methy 1 bromide for polyethylene-mulched tomato. Hortscience 32(7):1208-1211.

17- Nakayama, F. S.; D.A. Bucks, and A .J. clemmers. 1979. Assessing trickle emitter application uniformity. ASAE: 816-821. 
18- Ogg, A. G.; C .C. Dowler; A. R. Maryin; A. H. Lange and P. E. Heikes. 1983. Application of herbicides through irrigation systems, Ext.Service, USDA, item ADFO- 2280, pp 8.

19- Quinlan,J.D. and E.M. Pakenham. 1984. Effects of manual and chemical control of lateral shoots on the growth of young ornamental trees. East Malling Research Station, Maidstone ME19 6BJ, UK. Journal-of-Horticultural-Science. 59 :( 1): 4550; 7 ref.

20- Rajeshwari. M, H .Zakir and H. Markus. 2011. Pesticide Residues in Urban Water Bodies- Organic Farming as a Community Based Mitigation Strategy in Hyderabad Peri-Urban Area. Source OAI. Article · January 2011.

21- Regnault,Y. 1986. Weed control in soybeans. CETIOM, 75116 Paris, France: Information's -Techniques,-CETIOM.94, : 166-169.

22- Rutgers: New Jersey Agricultural Experiment Station (2018) .Mid-Atlantic Commercial Vegetable Production Recommendations. C Irrigation Management .P (56).

23- Sultan, W.M.M., 2002. Management of chemication under new land condation. PH.D.Thesis Agri.Eng.Dep.,Faculty of Agri.Al-Azher University, Egypt: 36-40.

24- Threadgill, E. D. (1991a). Advances of irrigation / fertigation and Chemigation. Proc.of the Expert Consultation on Fertigation / Chemigation. FAO, Sept 8-11., Cairo, Egypt: 30-44; 156-172.

25-Threadgill, E. D. (1991b). Chemigation and plant protection. Proc. of the Expert consultation on Fertigation /Chemigation. FAO, Sept 8-11., Cairo, Egypt: 156172.

26-Threadgill, E.D., D.E. Eisenhauer, J.R. Young, and B. Bar-Yosef. 1990. Chemigation. In Management of Farm Irrigation systems, (G.J.Hoffman, T.A. Howell, and K.H Solomon, St. Joseph, Mich, :ASAE.No: 749-775). 


\section{استخدام الرى الكيميائى فى تقليل تلوث ثمار البسلة \\ بالمبيدات فى الأراضى المستصلحة الجديدة فئرة}

\section{أحمد عبد العاطى حسين}

$$
\text { معهد بحوث الهندسة الزراعية - مركز البحوث الزراعية - دقى - جيزة- مصر }
$$

تم أستخدام أنظمة الرى بالتتقـــط السطحى و تحت السطحى مع تصرفات 8 و 12 لتر/ســاعة

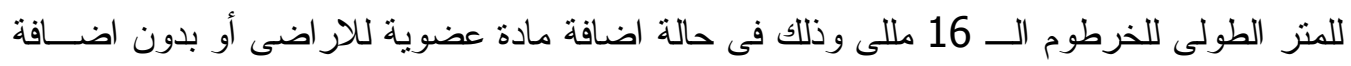

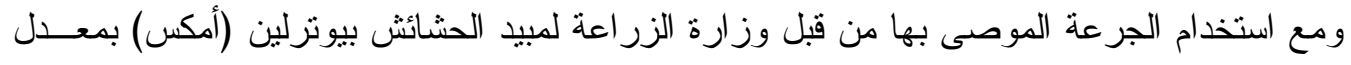

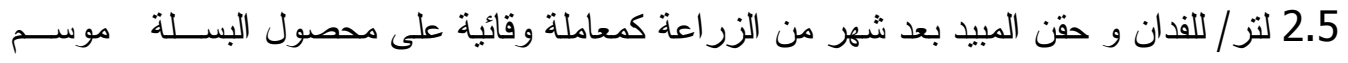
2016 وذللك لإلقاء الضوء على إمكانية استخدام الرى الكيميائى فى تقليل تلوث ثمار البسلة بالمبيدات تحت ظروف الأر اضى المستصلحة الجديدة .

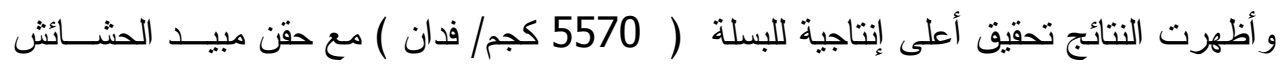

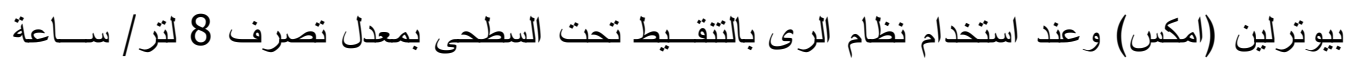

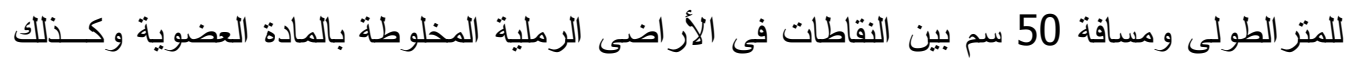

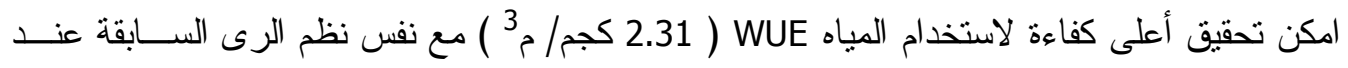

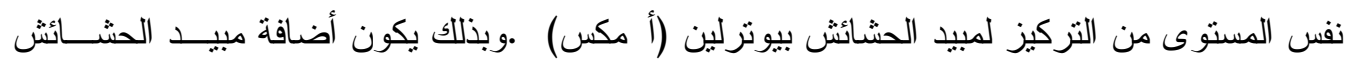
بيوترلين أمكس مع نظام الرى بالتقفيط التحت سطحى ومسافة بين النقاطات 50 سم أثنتت انها أكثـر

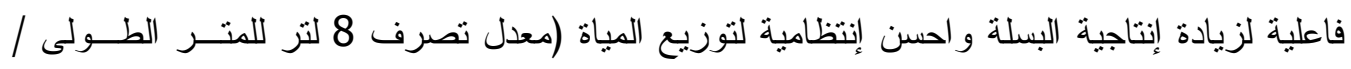
(الساعة). و أظهرتحليل عينات من ثمار البسلة بعد الحصاد من القطع المعاملة عدم وجود متنقيات المبيد فى المى

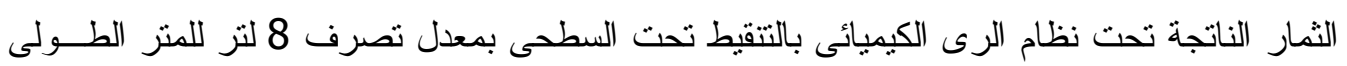

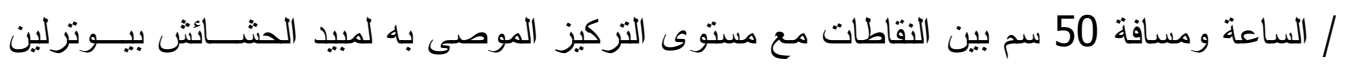
(أمكس) فى الأراضى الجديدة الرملية مخلوطة بالمادة العضوية. 
